\title{
osce Addresses Organized Crime through Police Co-operation
}

\author{
Alexey L. Lyzhenkov \\ First Director of the Transnational Threats Department of the oscE \\ Secretariat (2012-2016); Minister Extraordinary \& Plenipotentiary; \\ Ministry of Foreign Affairs, Moscow, the Russian Federation \\ alyzenkov@gmail.com
}

\begin{abstract}
Organized crime, along with terrorism, drugs, corruption and cyber-crime remain among the most significant threats to security and co-operation in the OSCE region. What has been achieved over these years and what else still needs to be done to ensure that organized crime does not hinder sustainable economic and social development in the area from Vancouver to Vladivostok?

To effectively defend the human rights of 1.2 billion people living in the region, the osce has to review its anti-crime toolbox from time to time, to strengthen its co-operation with other interested partners and to develop new mechanisms of cooperation among its 57 participating States. This article will focus on the ongoing efforts by the OSCE to combat organized crime through police co-operation.
\end{abstract}

\section{Keywords}

security and co-operation - rule of law - criminal justice - law-enforcement organized crime - police - human rights and fundamental freedoms

\section{Introduction}

Organized crime, along with terrorism, drugs, corruption and cyber-crime remain among the most significant threats to security and co-operation in the OSCE region. As far back as 1996 Heads of State or Government of the OSCE participating States expressed their concern over the threat the above-mentioned

(C) ALEXEY L. LYZHENKOV, 2019 | DOI 10.1163/18750230-02801005

This is an open access article distributed under the terms of the prevailing CC-BY-NC license at the time of publication. 
challenges constitute to the entire oSCE community. What has been achieved over these years and what else still needs to be done to ensure that organized crime does not hinder sustainable economic and social development in the area from Vancouver to Vladivostok? The UN Secretary-General said in his foreword to the United Nations Convention against Transnational Organized Crime:

If crime crosses borders, so must law enforcement. If the rule of law is undermined not only in one country, but in many, then those who defend it can not limit themselves to purely national means. If the enemies of progress and human rights seek to exploit the openness and oppportunities of globalization for their purposes, then we must exploit those very same factors to defend human rights and defeat the forces of crime, corruption and trafficking in human beings. ${ }^{2}$

To effectively defend the human rights of 1.2 billion people living in the region, the OSCE has to review its anti-crime toolbox from time to time, to strengthen its co-operation with other interested partners and to develop new mechanisms of co-operation among its 57 participating States. This article will focus on the ongoing efforts by the OSCE to combat organized crime through police co-operation.

\section{The osce Normative Basis to Address Organized Crime}

At their summit in Lisbon on 3 December 1996, the Heads of State or Government of the OSCE participating States adopted the Lisbon Declaration on a Common and Comprehensive Security Model for Europe for the Twenty-First Century. In this Lisbon Declaration they stressed that:

drawing strength from our diversity, we shall meet these challenges [of a criminal nature, $\mathrm{AL}$ ] together, through the OSCE and in partnership with other international organizations. Our approach is one of co-operative security based on democracy, respect for human rights, fundamental freedoms and the rule of law, market economy and social justice.

1 Lisbon Declaration on a Common and Comprehensive Security Model for Europe for the Twenty-First Century, DOC.S/1/96, Lisbon 3 December 1996, p. 10.

2 United Nations Convention against Transnational Organized Crime and Protocols Thereto, UN, New York, 2002, p. iii. 
It excludes any quest for domination. It implies mutual confidence and the peaceful settlement of disputes. ${ }^{3}$

Three years later, during the Istanbul summit in November 1999, the Heads of State or Government specified in the Charter for European Security that organized crime and drug trafficking, international terrorism and violent extremism represent growing challenges to security. They agreed that participating States would work to enhance the OSCE's role in police-related activities through:

- Police monitoring, including with the aim of preventing police from carrying out such activities as discrimination based on religious and ethnic identity;

- Police training, which could, inter alia, include the following tasks:

- Improving the operational and tactical capabilities of local police services and reforming paramilitary forces;

- Providing new and modern policing skills, such as community policing, and anti-drug, anti-corruption and anti-terrorist capacities;

- Creating a police service with a multi-ethnic and/or multi-religious composition that can enjoy the confidence of the entire population;

- Promoting respect for human rights and fundamental freedoms in general. ${ }^{4}$

The Charter for European Security also included agreement to "encourage the provision of modern equipment appropriate to police services that receive training in such new skills". ${ }^{5}$ In addition, participants of the summit underlined that the OSCE would "examine options and conditions for a role in law enforcement". 6

The Heads of State or Government declared that they would "also promote the development of independent judicial systems that play a key role in providing remedies for human rights violations as well as providing advice and assistance for prison system reforms". The OSCE was guided by the participating States' leaders to "work with other international organizations in the

3 Lisbon Declaration on a Common and Comprehensive Security Model for Europe for the Twenty-First Century, DOC.S/1/96, Lisbon 3 December 1996, p. 10.

4 OSCE, Istanbul Summit, 1999, Charter for European Security, para. 44.

5 Ibid.

6 Ibid.

7 OSCE, Istanbul Summit, 1999, Charter for European Security, para. 45 . 
creation of political and legal frameworks within which the police can perform its tasks in accordance with democratic principles and the rule of law".8

During the eighth osCE Ministerial Council in Vienna (2000), the Permanent Council was instructed to further examine the OSCE's role in police-related activities with a view to giving effect to the provisions of the just-described paragraphs 44 and 45 of the Charter for European Security. The tasking to the Permanent Council also included a further study as how to strengthen the capabilities of the Secretariat, as well as the possibility of establishing a new post of Police Adviser at senior level within the Secretariat. ${ }^{9}$

The following year Decision No.9 on police-related activities was adopted at the ninth Bucharest Ministerial Council (2001). By taking this decision participating States agreed that the OSCE would:

- strive to ensure continuity in institution building and functional transition from and disengagement of international assistance;

- explore and build on the role of police training, particularly integrated police training, in

creating police services that can enjoy the confidence of the entire population, and as a confidence-building measure;

- examine the options and conditions for an OSCE role in law enforcement. ${ }^{10}$

In support of such and other related activities and undertakings, they also agreed "to convene as appropriate and preferably annually meetings of police experts from OSCE participating States, and representatives of other relevant specialized international and regional organizations".11

The $11^{\text {th }}$ OSCE Ministerial Council, held in Maastricht in 2003, noted that globalization and technological advances increased the scope and extent of the threat caused by organized crime. ${ }^{12}$ It was recognized that organized crime often runs parallel with terrorism, in terms of both actors and methods. Smuggling of migrants and trafficking in human beings, illicit trafficking in narcotic drugs, in small arms and light weapons as well as in sensitive materials and

\footnotetext{
8 Ibid.

9 Decision of the Vienna Ministerial Council on police-related activities, $\mathrm{MC}(8) . \mathrm{DEC} / 7$, Vienna, 28 November 2000.

10 Decision No. 9 police-related activities, MC(9).DEC/9, Bucharest 3-4 December 2001.

11 Ibid.

12 Osce Strategy to Address Threats to Security and Stability in the Twenty-First Century, MC.DOC/1/03, Maastricht, 2 December 2003, p. 2, para. 11.
} 
technologies, were considered to be other criminal activities that might pose a threat to stability and security, both inside and outside the OSCE area. The Ministerial Council stressed that open borders and free movement of persons and goods were beneficial to international co-operation, but presented at the same time growing challenges, like illegal migration.

Therefore, the Ministers agreed that the OSCE would step up its work to combat organized crime. Regular meetings of police experts from the OSCE participating States and representatives of other relevant specialized international and regional organizations were to constitute an important contribution in this respect.

The Strategic Police Matters Unit was set up in the osce Secretariat pursuant to the OSCE Strategy to Address Threats to Security and Stability in the Twenty-First Century, ${ }^{13}$ which was adopted by the $11^{\text {th }}$ Ministerial Council, with the view to improve capacity of the participating States to address threats posed by criminal activity and to assist them in upholding the rule of law. ${ }^{14}$ The aim was to enhance key policing skills, including respect for human rights and fundamental freedoms. The OSCE was supposed, at the request of the participating States, to increase its focus on assistance to authorities, including at the local level, on fighting crime and criminal networks and to define and develop core competencies for police activities such as training and capacity-building.

Two years later, at the $13^{\text {th }}$ Ministerial Council (Ljubljana, $5^{-6}$ December 2005) Decision N $N^{o} .3 / 05$ on combating transnational organized crime ${ }^{15}$ was adopted, stressing again the importance of co-operation on this important issue.

This was followed by the Brussels Declaration on Criminal Justice Systems, ${ }^{16}$ adopted by the $14^{\text {th }}$ OSCE Ministerial Council on $4-5$ December 2006. The Declaration underscored the joint work conducted in that area and recalled the importance of judicial independence, impartiality, integrity, equality of treatment to all before the courts and other principles, inherent to a just and fair criminal justice system.

\footnotetext{
13 Ibid.

14 OsCE Strategy to Address Threats to Security and Stability in the Twenty-First Century, MC.DOC/1/o3, Maastricht, 2 December 2003, p. 6, para. 32.

15 Decision on combating tansnational organized crime, MC.DEC/3/05 Ljubljana, 6 December 2005 .

16 Brussels Declaration on Criminal Justice Systems, MC.DOC/4/o6, Brussels 5 December 2006.
} 
The Criminal Justice Assessment Toolkit, presented at the $14^{\text {th }}$ Ministerial Council, was developed and produced by the OSCE and UNODC experts to help countries make their criminal justice systems more effective and to assist practitioners to reform their own criminal justice systems, bringing them in line with international standards. It was also aimed to enable international advisers to conduct assessments of the justice systems in individual countries and to identify areas for appropriate technical assistance. The toolkit covered policing, access to justice, prison and alternatives to incarceration, and other issues such as juvenile justice and the treatment of victims and witnesses. Divided into 16 modules, it provided detailed and comprehensive guidance for practitioners.

The osce Chairperson-in-Office, Belgian Foreign Minister K. De Gucht, said the tools were designed to be widely applicable:

I am convinced the tools will make a difference for the people doing rule of law work on the ground, within the OSCE but also beyond. As you are aware, rule of law and good governance are "growth areas". The international community is increasingly being called upon to provide rule of law assistance. I am certain that the tools we are launching today will facilitate that work and raise the standards for international rule of law assistance. ${ }^{17}$

By Decision N No.5/o6 on organized crime ${ }^{18}$ (Brussels, 5 December 2006), the Ministers invited the participating States to consider undertaking a self-assessment of their criminal justice systems, using, as appropriate, instruments available from international organizations, such as the OSCE-UNODC Criminal Justice Assessment Toolkit. The oscE participating States were also urged to pay due attention to the integrity and professionalism of law enforcement agencies and prosecution authorities, to administrate efficiently justice and implement proper management of the court system, to ensure independence of the judiciary and the proper functioning of the penitentiary system and to explore alternatives to imprisonment.

In the Astana Commemorative Declaration: Towards a Security Community, ${ }^{19}$ adopted by Heads of State or Government at their summit meeting in the Kazakhstan capital on December 2010, they reconfirmed the Organization's

\footnotetext{
17 Newsrelease, Brussels, 4 December 2006.

18 Decision on organized crime, MC.DEC/5/06, Brussels, 5 December 2006.

19 Astana Commemorative Declaration: Towards a Security Community, SUM.DOC/1/10/ Corr.1, Astana, 3 December 2010.
} 
comprehensive approach to security based on trust and transparency. ${ }^{20}$ Recognizing that by definition no one state or organization can effectively tackle transnational challenges alone in the complex and inter-connected world, the Heads of State or Government agreed in the Astana Commemorative Declaration that they "must achieve greater unity of purpose and action in facing emerging transnational threats, such as terrorism, organized crime, illegal migration, proliferation of weapons of mass destruction, cyber threats and the illicit trafficking in small arms and light weapons, drugs and human beings". 21

The OSCE participating States were in agreement to take advantage of the Organization's broad membership, thematic expertise and comprehensive approach to security and develop collective responses that cut across the politico-military, economic and environmental, and human dimensions of security.

Various forms of criminal activity, especially that of organized criminal networks, may be effectively dealt with only when participating States closely co-operate with each other, when they agree on needs assessment, capacitybuilding, institution-building, training and evaluation, and when they provide necessary support to each other. Among the decisions welcomed by the $19^{\text {th }}$ Ministerial Council in Dublin in 2012 was the OSCE Strategic Framework for Police-Related Activities, ${ }^{22}$ which defines pertinent priority areas and aims to facilitate the streamlining of the OSCE's activities in all areas related to policing within the Organization's wide approach to security. Some specific outputs in capacity-building include training of police and law-enforcement; the development of strategic planning activities; the creation of a transparent, effective, efficient human resources management system for police; and the development of police accountability structures.

\section{os CE Efforts to Address Organized Crime through Police Co-operation}

The OSCE is covering almost all aspects of transnational threats, including organized crime. However, since discussing all these aspects would require many

20 Newsrelease, Astana declaration adopted at OSCE Summit charts way forward, 2 December 2010.

21 Astana Commemorative Declaration: Towards a Security Community, SUM.DOC/1/10/ Corr.1, Astana, 3 December 2010.

22 OSCE Strategic Framework for Police-Related Activities, PC Decision № ${ }_{1049}$, Vienna, 26 July 2012. 
morepages, hereafterletusfocus, in particular, on theosCE's police-relatedactivities in combating organized crime. Various criminal challenges are discussed and police-related responses to them are developed by police experts from OSCE participating States at their annual meetings. Representatives of relevant specialized international and regional organizations also contribute to these deliberations. Annual Police Experts Meetings (APEM) are held by the osce since 2003 following Ministerial Council Decision No. 9, adopted in Bucharest (2001). ${ }^{23}$ Over the years the following topics have been discussed by the APEM:

2003 human trafficking, especially that of women and children;

2005 Improving the effectiveness of law-enforcement in preventing and combating hate crimes;

2008 Fighting the threat of cyber-crime;

2009 Hate crimes and effective law-enforcement co-operation;

2010 Opportunities for further enhancing OSCE police-related activities; 2011 Harmonization of police reform with the reform of the wider criminal justice system;

2012 Fighting the threat of cyber-crime;

2013 Improving the role of the OSCE in police-related activities: experiences and lessons learned;

2014 Enhancing cross-border co-operation of the criminal justice system in combating transnational crime in the OSCE area;

2015 Fighting organized crime in the OSCE area with a focus on trafficking in human beings and irregular migration;

2016 Intelligence-led policing: a model for strategic planning, strengthening community policing and countering transnational threats posed by criminal activity;

2017 Crime should not pay: illicit financial flows and confiscation of criminal assets. Countering financial proceeds of criminal networks.

2018 Future policing strategy: addressing trends and changes in a globalized world.

The results of all these meetings were addressed in my recently published book on OSCE and Transnational Threats ${ }^{24}$ and let me refer the reader to this publication for a more thorough analysis of these fora. Here I just want to mention

23 Decision No. 9 police-related activities, MC(9).DEC/9, Bucharest, 3-4 December 2001.

24 Alexey Lyzhenkov, osce vs. Transnational Threats: Past, Present, Future (LAP Lambert Academic Publishing 2018), 139 pp. 
a few other important police-related events which have been organized by the OSCE over the past years.

The Belgian 2006 OSCE Chairmanship, with the support of the Strategic Police Matters Unit in the OSCE Secretariat, hosted the first Chiefs of Police meeting in Brussels on 24 November 2006. This one-day meeting was the first of its kind in the OSCE region. The event, organized at the initiative of the osce Chairperson-in-Office, Belgian Foreign Minister K. De Gucht, brought together more than $5^{0}$ Chiefs of Police from the OsCE participating States. Speaking on behalf of the OSCE Chairperson-in-Office K. De Gucht and the Belgian Minister of the Interior P. Dewael,Special Envoy P. Chevalier noted: "Belgium decided to bring together police chiefs because it is the real professionals who need to exchange information, investigate suspects, bring them to justice. Police officers need to be able to rely on the full co-operation and readiness of colleagues and judicial structures in all countries concerned". ${ }^{25}$ Belgian Commissioner General H. Fransen added:

The presence of more than 50 chiefs of police shows that they are aware of the important contribution police services provide toward security. In fact, the development of a democratic society would be impossible without their efforts and collaboration. But the police services involved in international collaboration must also realize that they have to respect and safeguard the democratic rights and liberties of citizens in all countries concerned. ${ }^{26}$

The meeting aimed to identify problems in police co-operation and propose solutions; enhance awareness of these issues at the political level; increase operational co-operation among police services, and increase the protection of citizens' rights and freedoms in the conditions of growing international police co-operation. ${ }^{27}$

The meeting's first session was devoted to a comprehensive threat assessment determining priorities for co-operation. The second session addressed co-operation in practice: obstacles, best practices and opportunities. The third session discussed democratic policing - safeguarding main principles in conditions of expanded police co-operation.

The Brussels Statement, ${ }^{28}$ adopted by the meeting, addressed the following themes:

\footnotetext{
25 Newsrelease, Brussels, 24 November 2006.

26 Ibid.

27 Annual Reprort of the Secretary General on police-related activities in 2006, p. 25 .

28 OsCE Chiefs of Police meeting, Brussels Statement, 24 November 2006.
} 
- the OSCE role in combating organized crime;

- strategic risk and threat analyses for law enforcement purposes;

- co-operation among national police services to combat organized crime;

- democratic oversight to ensure accountability of law enforcement.

The Chiefs of Police of the OSCE participating States agreed to intensify international police co-operation to better fight organized crime and improve security. To meet this goal they also included in the Brussels Statement their proposal to meet within the OSCE every three years. ${ }^{29}$

A new online information system offering OSCE participating States access to information on police-related assistance was launched during the meeting as well. The system, dubbed POLIs (Policing Online Information System), has developed over the years into a comprehensive, multi-lingual resource that consolidates all aspects of law enforcement activities within the OSCE area, including police assistance, training techniques and funding opportunities. Its objective is to make this a vast storehouse of information available to interested parties and to create a virtual community of policing experts.

In May 2007 the two-day event, Strengthening police role and co-operation in combating terrorism, was organized by the Spanish 2007 OSCE Chairmanship, the Strategic Police Matters Unit of the osce Secretariat and the Spanish Interior Ministry. It brought together over 6o experts from osCE participating States, Partners for Co-operation and international organizations. They discussed the role intelligence-led and community-based policing can play in preventing terrorism activities, police practices in investigating logistics and communications used by terrorists, ways to protect the rule of law in the fight against terrorism, and the situation in the Mediterranean and South-Eastern Europe. $^{30}$

In September 2007, the OSCE hosted a law enforcement conference on Improving law enforcement's response to combat sexual exploitation of children on the Internet. ${ }^{31}$ Participants were informed about several high-quality training courses available to their law enforcement agencies at no cost. There was also a demonstration of the latest technology investigators could use to combat this type of crime. Experts from Austria, Belgium and the Russian Federation made presentations on contemporary cases that were successfully investigated.

29 Ibid.

3o Newsrelease, Madrid, 9 May 2007.

31 Annual Report of the Secretary General on police-related activities in 2007, SEC. DOC/2/08, 25 September 2008, p. 14. 
A special session was devoted to the ways of improving law enforcement co-operation with the private sector. Representatives from Microsoft, VISA, Internet Service Providers, Hotline operators, and specialized NGOs participated in the conference. Participants also addressed the issue of building effective partnerships with the criminal justice sector.

\section{os CE Co-operation with Partners in Addressing Organized Crime}

Both at the planning and implementation level, the OSCE closely co-operates and co-ordinates its efforts to counter crime with interested international organizations and forums. Among these, UNODC plays an important role having a mandate to provide technical assistance in response to crime prevention and criminal justice. Today this co-operation has an impressive and solid institutional basis - the fourth OSCE-UNODC Joint Action Plan for the period 2018-2019 was signed on 31 January 2018.

Co-operation with INTERPOL is based on the Memorandum of Understanding between the OSCE Secretariat and INTERPOL General Secretariat, signed on 27 May 2014. The Memorandum provides a framework for increased cooperation and sharing of resources for police training and capacity-building. Another important step was made on 16 May 2017 when a Joint Action Plan for 2017-2020 was signed. The three-year plan identifies priority areas for joint capacity-building activities to strengthen performance of INTERPOL National Central Bureaus and the Border Crossing Points of OsCE participating States.

The OSCE and the Police Co-operation Convention for Southeast Europe (PCC SEE) have also long and well established relations. On 11 May 2016 OSCE representatives participated in the $15^{\text {th }}$ meeting of the PCC SEE Committee of Ministers on the occasion of the tenth Anniversary of the signing of the PCC SEE in Vienna. ${ }^{32}$

Presenting the OSCE Guidebook on Intelligence-Led Policing at the headquarters of the League of Arab States in Cairo on 14 November $2018^{33}$ marks another important step to strengthen and operationalize police co-operation between OSCE participating States and OSCE Partners for Co-operation Algeria, Egypt, Jordan, Morocco, Tunisia, as well as with other members of the League.

\footnotetext{
32 Annual Report of the Secretary General on police-related activities in 2016, SEC.DOC/1/17 Rev.1, 27 July 2017, p. 19.

Newsrelease, 14 November 2018.
} 


\section{Possible Next Steps}

To effectively combat crime in the OSCE region, participating States and their law-enforcement agencies, along with other sectors of the criminal justice system, need to co-operate closely and in good faith. Taking into account the current political atmosphere in the Organization an important practical step to strengthen police co-operation might be to arrange a second meeting of Chiefs of Police in the nearest future. Would the Slovakia 2019 OSCE Chairmanship not like to contemplate such a possibility?

As explained, the first Chiefs of Police meeting was hosted by the Belgian 2006 OSCE Chairmanship in Brussels on 24 November 2006. Participants discussed problems in police co-operation and proposed solutions; enhanced awareness on these issues at their level; took efforts to increase operational co-operation among police services, and to increase the protection of citizens' rights and freedoms. ${ }^{34}$

The Chiefs of Police of the OSCE participating States agreed in the Brussels Statement, adopted by the meeting, to intensify international police cooperation to better fight organized crime and improve security, and to meet within the OSCE every three years. ${ }^{35}$ The author was unable to find traces of any other OSCE meeting of such a kind since 2006. Should the decision makers not take the lead and guide their experts accordingly? Building on the outcomes of their first meeting Chiefs of Police might focus, for example, on the following thematic prirorities of the OSCE's police-related activities, as they are identified in the OSCE Strategic Framework for Police-Related Activities: ${ }^{36}$

- general police development and reform;

- organized crime;

- terrorism;

- illicit drugs and chemical precursors;

- trafficking in human beings;

- cyber-crime;

- co-ordination and co-operation among OsCE participating States;

- co-operation with partner organizations.

34 OSCE Chiefs of Police meeting, Brussels Statement, 24 November 2006.

35 Ibid.

36 osce Strategic Framework for Police-Related Activities, PC Decision №1049, Vienna, 26 July 2012. 
In November 2006 the first regional workshop of Police Academies in Central Asia was held in Kyrgyzstan. Since 2012, the OSCE Secretariat's Transnational Threats (TNT) Department has been undertaking efforts to create the osCE Police Academies Network (PAN) to promote and support international police training and co-operation. On 29 June 2018 these efforts finally resulted in establishing such a network in Vienna. ${ }^{37}$ The Network will launch an online platform that offers a complete overview of education and training sources, thus facilitating the exchange and mutual use of existing resources, including curricula, modules, training materials and expertise within law enforcement training institutions in the OSCE area.

The objectives of the PAN are:

- to facilitate, promote and support exchanges of best practices, communication, information and material in the field of law enforcement training among participating States;

- to provide ground for collaboration of law enforcement training institutions in developing content and methodology within the OSCE participating States.

The Chiefs of Police would certainly welcome the establishment of PAN and its accessibility to the OSCE partner organizations and networks, such as the UNODC, LE TrainNet, the European Union Agency for Law Enforcement Training (CEPOL), the Association of European Police Colleges (AEPC), etc. What might be even more important is that the PAN platform should be used by all 57 OSCE participating States. One can hardly overestimate the role of Chiefs of Police in setting the patterns of PAN operational use and development.

After the presentation of the OSCE Guidebook on Intelligence-Led Policing in the headquarters of the League of Arab States ${ }^{38}$ co-operation between the OSCE and the League is to be intensified, and contacts at an expert level are to be expanded. Ministers of the Interior of the League meet regularly on a bi-annual basis to discuss different issues, including co-operation with partners. What mechanisms may the osce use to develop vision and strengthen interaction in the area of police and police-related activities with partner organizations, such as UNODC, INTERPol, Police Co-operation Convention for Southeast Europe, European Network of Police Women, League of Arab States, and many others? Would the OSCE Chiefs of Police meetings from time to time not be of practical use in this regard as well?

$37 \quad$ Newsrelease, Vienna, 29 June 2018.

38 Newsrelease, Cairo, 14 November 2018. 